\title{
Mining-Induced Displacement and Resettlement: An analytical Review
}

\author{
Robson Mandishekwa \\ (Corresponding author) \\ Midlands State University, Faculty of Commerce, \\ Department of Economics, Gweru, Zimbabwe \\ Email: rmandishekwa@gmail.com or mandishekwar@staff.msu.ac.zw

\section{Enard Mutenheri} \\ Midlands State University, Faculty of Commerce, \\ Department of Economics, Gweru, Zimbabwe \\ Email:e.mutenheri@yahoo.com \\ DOI//http://dx.doi.org/10.4314/gjds.v17i1.6
}

\begin{abstract}
Generally, mining-induced displacement has been less considered in research on development-induced displacement. Specifically, economists have relegated displacement studies to other disciplines despite displacement's economic relevance. This paper seeks to outline development-induced displacements and their linkages with economic activities and life satisfaction among the displaced in post-displacement location. To attain this, an integrated literature review was done. Findings indicate scarcity of literature on economic consequences of mining-induced displacement and its linkage with economic activities and life satisfaction. A theoretical proposition for these linkages is made. The study also reveals that mining-induced displacement is equally important in displacement studies. The study recommends that economists must put more effort in mining-induced resettlement studies given that it has the potential to resettle more people.
\end{abstract}

Keywords: Mining, Economic Consequences, Development, Life Satisfaction, Economic Activities

JEL codes: Q34, R23, Z13 


\section{INTRODUCTION}

Population displacement is becoming an increasing challenge in many countries. During the 1980s, the study of forced migration gained greater recognition (HarrelBond \& Voutira, 1992) with internal displacement occupying a central place especially in Africa (Lwabukuna, 2011) resulting in Internally Displaced Persons (IDPs). No universal definition for IDPs exists yet. IDPs are defined as people who were forced to migrate but do not cross recognised international borders (IDMC, 2008). UN (2004, p.1) defines IDPs as “...persons or groups of persons who have been forced or obliged to flee or to leave their homes or places of habitual residence, in particular as a result of or in order to avoid the effects of armed conflict, situations of generalised violence, violations of human rights or natural or human-made disasters, and who have not crossed an internationally recognised state border". From the two definitions, what distinguishes a refugee from an IDP is whether the migrant crosses an international boarder or not. Those who cross borders are refugees while those who do not are IDPs. Mooney (2003) alternatively defines IDPs as internal refugees while Opukri and Ibaba (2008) view them as aliens in their own communities. The definition by Opukri and Ibaba (2008) seems to infer that IDPs are a result of displacement in situ, where IDPs only move a few kilometres from their place of residence thereby cohabiting with their displacer. Opukri and Ibaba (2008) conclude that IDP definitions are narrow. While definitions by IDMC (2008) and UN (2004) connote that IDPs do not cross international borders, the one by Opukri and Ibaba (2008) is silent on that. Therefore, the definition of IDPs remains somehow equivocal although it seems acceptable that IDPs are forced migrants.

Although no accurate statistics on IDPs exist, the approximate statistics are alarming with millions of people displaced each year. In 1997, 17 million people were displaced (Bozzoli, Bruck \& Muhumuza, 2011) while the figure rose to 21.8 million in 2002 (United States Committee for Refugees, 2002). Twenty seven and a half million individuals were displaced in 2010 (Bozzoli et al., 2011) while the United Nations High Commission for Refugees (UNHCR, 2010) estimated that 44 million people were displaced globally in 2010. During 2015 alone, 27.8 million new displacements occurred (IDMC, 2016) while in 2017, 30.6 million IDPs were recorded (IDMC, 2018). Again, at the end of 2017, at least 40 million people remained internally displaced.

Conflict has become a prominent cause of displacement. For instance, Boko Haram uprooted 1782490 individuals as of 2017 (KNOMAD, 2018). In 2014, 38 million people became IDPs due to conflict and violence with 11 million new IDPs (IDMC, 2015a). For 2015 alone, several millions of people were subjected to conflict-induced 
displacement (IDMC, 2016). DRC was first in Africa and second from Syria in the world rankings with a total of 2.2 million people being displaced in 2017 (IDMC, 2018). These figures speak volume about the intensity and severity of displacements in the current century. Therefore, academics and policymakers need to pay particular attention to issues of displacement for inclusive development to be attained.

Natural disasters have cropped up as a cause of displacement. In Zimbabwe, 800 people were natural disaster-displaced in 2015 (IDMC, 2016) with the figure rising to 10000 in 2017 (IDMC, 2018). Again, in Zimbabwe, the major natural disasters causing displacements are cyclones, for instance, Cyclone Eline, and Cyclone Idai. As of 21 March 2019, UNICEF (2019) noted that 250 ooo people were victims of Cyclone Idai.

Extant literature suggests DID as one major cause for concern. For example, Kariba dam displaced 57 ooo people (Cernea, 1997; Hughes, 2006) while Magadza (1994) estimated the figure at 86 ooo. Cook and Mukendi (1994), however, estimated the figure at 67 ooo. These variations indicate that IDP figures remain estimates. In India, 21 ooo families were relocated to pave way for Pong Dam construction (Lama, n.d). MID has also caused major displacements. For instance, Murowa and Chiadzwa diamond (both in Zimbabwe) have caused uprooting of people. Despite displacing a significant number of households, 265 graves were displaced by Murowa diamonds (Terminski, 2012) while Chiadzwa diamonds uprooted 930 households as of 2017. Development-induced displacement and resettlement (DIDR) displaced several households in Chisumbanje, Zimbabwe, for bio-fuel production. In Ghana, bio-fuel projects have resulted in significant displacements (Agbley, 2019). Unlike, most DIDs, mining-induced displacement (MID) remains understudied, therefore, its unique consequences remain unknown.

The study was motivated by the fact that most economists have relegated the study on economic consequences of internal displacement to anthropologists and other disciplines despite the fact that displacement has economic consequences. Thus, the scarcity of literature on economic consequences of displacement (Ruiz \& VargasSilva, 2013; Owen \& Kemp, 2015) has been one major reason for this study. Cernea (1999), Cernea (2003), Dwivedi (2002) and Jacobsen and Landau (2003) concur that economics is a candidate for studies on displacement. Furthermore, McDonaldWilmsen and Webber (2010) noted that economics has only been consulted to provide solutions on cost minimisation. As a cost-cutting measure, dam-induced 
displacements are conducted hastily (Eriksen, 1999) thereby avoiding certain considerations like changes in economic activities and satisfaction with life (SWL).

The study contributes to existing literature in that MID has been under studied while other DIDs have been well studied, despite MID having consequences needing attention (Hoadley, 2008). Additionally, MID has led to a large number of displacees (Terminski, 2012). Also, MID is unique in various ways (Owen \& Kemp, 2015, Kemp, Worden \& Owen, 2016). Owen and Kemp (2015) noted that MID is unique because resettlement can take place at any stage of the project. Thus, even if displacement may take place at the beginning of mining, additional land, possibly because of attractive commodity prices, may be required resulting in more displacements. Therefore, mines sometimes use a "stepwise mining expansion and land take" (Downing, 2014, 8) approach. Owen and Kemp (2015) also cited cohabitation between miners and IDPs like what happened at Lihir mine, with pollution affecting IDPs. This resembles what Magaramombe (2010) termed displacement in situ. Therefore, MID remains a unique displacement that deserves attention.

Therefore, the main objective of the study is to show that MID has been less considered in research on DID and that economic consequences of displacement have a bearing on economic activities and SWL after displacement. The specific objectives are: firstly to show that out of all DIDs, MID is understudied. Secondly, the study shows that economists have relegated research on DID to other disciplines despite its economic relevance. Therefore, knowledge of economic consequences of displacement is still scarce. Thirdly, the intention is to show, theoretically, that displacement consequences have linkages with economic activities and SWL among IDPs.

Knowing internal displacement's consequences, its effects on livelihoods and SWL among IDPs is important for different reasons. Firstly, from the results, economists will be better informed in resettlement issues. Establishing the economic consequences of displacement enables an understanding of a development-led approach to displacement. Therefore, policy-makers will put measures that ensure minimum consequences of displacement and employ inclusive-growth enhancing livelihoods. A number of benefits from such a development-led approach can be tapped such as maximising the utility and harnessing productive assets of the displaced, enabling the displaced to contribute to public sector revenue and the development-led approach improves lives of the displaced through provision of resources (Zetter, 2014). 
This paper is divided into six sections. The next section considers empirical literature on forced migration, economic activities and SWL among forced migrants. It is followed by theoretical underpinnings that describe the relevant theories linking the three aspects. The methodology and discussions come next in that order. Findings and conclusions come last.

\section{Empirical Literature}

The world over, Africa hosts the majority of IDPs with two thirds of IDPs being found in Africa (Norwegian Refugee Council, 2017). In Africa, IDPs outnumber refugees hence the term Africa's new dilemma (Lwabukuna, 2011). That IDPs outnumber refugees is not unique to Africa since IDMC (2016) indicates that the 40.8 million people internally displaced in 2015 is twice the number of refugees. In Zimbabwe, The Social Development Notes (2009) estimated that between 570 ooo and one million people were internally displaced compared to 16841 refugees as of 2008. This indicates a huge disparity between the IDP population and refugees with IDPs outnumbering refugees (Cohen, 2000; Oucho, 2005; Ferris, 2012).

One surprising thing in DID is that despite the World Bank having put in place several guidelines to be observed before displacing people, governments use their power of eminent domain to continue displacing people (Vanclay, 2017). Therefore, Cernea (1997b: 23) noted: "These countries do have laws that empower the state to expropriate land "needed for the public good" and displace the owners of those lands" while Agbley (2019: 159) concurs by saying in Ghana “...the guidelines are just that, non-binding and non-enforceable”. Furthermore, in Zimbabwe, people have rights to use land but do not have the rights to the minerals underneath that land; therefore, justifying displacements when a mineral is discovered. The same applies in Laos where land is owned by the state but households have user rights (Vandergeest, 2003). The power of eminent domain, therefore, means that knowing or not knowing the guidelines is not different because governments continue to circumvent the guidelines using their powers. For instance, the Akosombo dam displaced 80 ooo IDPs (Stanley, 2004), Tarkwa district and New Mont mine displaced 30 ooo and 1701 people for mining, respectively (Aboagye, 2014, planningAlliance, 2005), despite Ghana having guidelines for displacement. The same happened when Kariba, Osborne and Tokwe-Mukosi dams were constructed in Zimbabwe. Merowe dam displaced hundreds of thousands of households (Gross; 2008). However, in the context of the power of eminent domain, governments are expected to compensate those whose properties have been expropriated, but in most cases households are 
not compensated (Adeola, 2017) probably because compensation policy, for instance in Ghana, does not consider tenancy of people who are displaced (Aboagye, 2014).

The aftermath of displacement has generally been overlooked by economists (Cernea, 1991, 1995, 1996, 997, 2003). Cernea (1995, 1997) identified eight consequences of displacement including landlessness, joblessness, marginalisation, loss of access to common resources and food insecurity, among others (Cernea, 1997, 1999; Hoshour \& Kalafut, 2007; Petkova, Lockie, Rolfe \& Ivanova, 2009; Carrillo, 2009). Food insecurity has been experienced among IDPs (Aboagye, 2014; IDMC, 2018). In Kenya, Mburugu (1994) noted that displacement led to landlessness and marginalisation.

Cernea (1997a, 200o) argues that people's livelihood hinges on land and expropriation of land will decapitalise IDPs. Through losing land, people lose both natural and man-made capital (Cernea, 1997a). Carrillo (2009) found that around 55\% of IDPs in Colombia had land before displacement, but on average lost 4 hectares. In Phillipines, Cagoco-Guiam (2013) found that conflict led to land losses. Kariba dam led to losses of land and common property resources (Hughes, 2006; Mashingaidze, 2012). With land being a key asset, its loss is detrimental to households' lives. Because most rural households are peasants, losing land leads to food insecurity (Yankson et al., 2017) and loss of income. Thus, semi-subsistent farmers earning an additional income from land lose it after displacement.

DIDR uprooted many people, with dams topping the list. Hundreds of thousands were displaced by Merowe dam in Sudan (Gross, 2008). Ghana's Akosombo and Bui dams displaced 80 ooo and 1216 people, respectively (Stanley, 2004; Koranteng \& Shi, 2018). The social consequences of displacement because of dams can now be considered known, although Cernea (1995a) claims that displacement consequences are project-specific. That dam-induced displacement consequences are now known seems unequivocal given that studies on dams resulted in the establishment of the World Commission on Dams (WCD). Such studies on dams include Scudder (1985), Magadza (1994), Cernea (1995a, 1997a, 1997b, 2003) and Hughes (2006). All these studies concur that dam-induced displacement leads to social consequences.

Mutopo (2011) conclude that bio-fuel companies displaced households in Nuanetsi, Zimbabwe. Agbley (2019) cited bio-fuel as a cause of displacement in Ghana. Oil extraction has also been found to lead to population displacement with Nigeria being an example (Opukri \& Ibaba, 2008). 
MID, on the other hand still remains understudied. Vesalon and Cretan (2012) specifically examined the complexity of the consequences of DIDR in Romania while Kemp, Owen and Collins (2017) focused on operationalisation of international commitments in mining. Additionally, Mandishekwa and Mutenheri (2018) studied the consequences of MID and found that IDPs lost land, jobs and income.

Consequentially, since displacement is a life-changing event, its effects on livelihoods and SWL among IDPs seems unequivocal, though little seems yet known about the links. Several authors, for instance, Bruck (2004), Bruck and Danzer (2007), Amisi (2006), Khawaja et al. (2008) and Bozzoli et al. (2011) concur that after displacement, household economic activities change. Changes in economic activities are necessitated by a plethora of factors, chief among them being the need to manage risk. Crop husbandry has been found to be the major economic activity among IDPs (Bruck, 2004; Adeniyi et al., 2016) possibly because of the need to be food self-sufficient. However, food crop production has proved to be problematic for IDPs because land will have been lost according to Cernea's (1997a) impoverishment risk and reconstruction (IRR) model. Cernea (1997a) indicates that most rural households depend on common property resources; therefore, its loss is likely to impoverish IDPs. Examples of common property resources include common grazing land and forestry. The entry of migrants into the host community also gives rise to competition for resources resulting in the tragedy of the commons by Hardin (1968). Cumulatively, these losses lead to use of coping strategies.

Because displacement is a stressful life event, it is likely to negatively affect SWL. This loss of happiness is analogous to loss of genuine wealth (Anielski, 2007). Although numerous studies on happiness exist, very few, consider SWL after displacement. Among the few to study SWL after displacement are Colic-Peisker (2009), Getanda et al. (2015), Ootegem and Verhofstadt (2016) and Mandishekwa and Mutenheri (2019). While Getanda et al. (2015) and Ootegem and Verhofstadt (2016) concentrated on mental health aspects of subjective well-being among IDPs, Mandishekwa and Mutenheri (2019) considered determinants of SWL among MID IDPs. Colic-Peisker (2009) studied refugees. The majority of findings from these studies indicate a change in resettlers' SWL. In most cases, IDPs tend to be overcrowded in camps increasing the spread of diseases. The amenities in those camps are mostly not enough to sustain stable lives. Since displacement affects economic activities, income is likely to be affected as well. Although income does not to buy happiness, it remains mostly an important determinant of SWL. 
From empirical literature, it may be plausible to conclude that MID remains understudied. Major focus has been on conflict and dam-induced displacement. Also, economists have been ignoring resettlement studies. The transmission mechanism from displacement to either economic activities or SWL after displacement also remains unknown.

\section{THEORETICAL UNDERPINNINGS}

From the perspective of neoliberal economics, nations benefit from displacements in terms of incomes and economic growth through exports (Agbley, 2019). However, Sen (1999) noted that even if a proportion of a cake is taken away from the poorest person and shared among the rich with the intention of achieving "majority improvement" achieving the improvement only works, given that the social judgement is by majority rule. This view seems to be in line with the KaldorHicks efficiency criterion but can also be perceived to be in contrast with the Pareto optimality criterion. Of note is that the neoliberal claim is less people-centred because it focuses less on the impact of the development project on the displaced persons yet Cernea $(1994,3)$ notes that 'It is essential for successful implementation of development projects to 'put people first". In line with this, Sen $(1999,252)$ says there is need for taking note of "... who gains how much in terms of welfare or of the basic ingredients of living, how is the cake being "earned" or "looted"”. Without taking cognisance of these then it is inevitable for decisions to be accommodative of everyone's needs.

The Kaldor-Hicks criterion argues that a welfare improvement will only occur if the losers consider their losses to be less than the gains by winners (Mathis \& Steffen, 2015). This conclusion, however, is difficult to reach considering that, usually losses get higher weights from rational individuals than gains. However, some IDPs may benefit from the project (Cernea \& Schmidt-Soltau, 2003). Considering Pareto optimality, displacing people for developmental reasons does not improve the majority's social welfare without affecting IDPs' welfare.

After being displaced, rational agents make decisions on economic activities to engage in. Vlaev (2018: 3) noted that “... concepts from evolutionary biology predict how an animal should respond to risk if it is maximising its fitness". Within that context, therefore, a household is expected to take certain risk management behaviours when they are displaced, to maximise utility. One notion that rational agents are assumed to obey is thoughtful deliberation (Lichbach, 2003; Rubinstein, 2006; Hodgson, 2012; Ritzer, 2011). 
Therefore, based on Pareto optimality and Kaldor-Hicks criterion, one may suggest a link between displacement and SWL. Rational choice theory may suggest a link between displacement and economic activities. The study, therefore, proposes that there exist linkages among displacement consequences, economic activities and SWL among IDPs. To summarise these linkages, a conceptual framework has been developed based on the attribution theory by Heider (Weiner, 1985, 2008; Malle, 2011), Pareto and Kaldor-Hicks efficiencies. The attribution theory argues that anything has a cause and people are interested in finding these causal relationships while Pareto suggests that this cause affects welfare. Attribution theory also notes that individuals are accurate in attributing these causes to effects. Therefore, relying on these theories, the study claims that, changes in economic activities and SWL among IDPs are attributed to displacement. These interrelationships are displayed in Figure 1.

Figure 1 shows that displacement has consequences (Arrow 1) as examined by the IRR model. The consequences are normally negative such as joblessness and marginalisation (Cernea, 1995, 1997a) but may be positive (Cernea \& SchmidtSoltau, 2003; Vanclay, 2017) such as access to better roads and having fertile soils. Therefore, Vanclay (2017) noted that IDPs may experience improvement in material standards of living but Cernea mostly view displacement as having negative consequences.

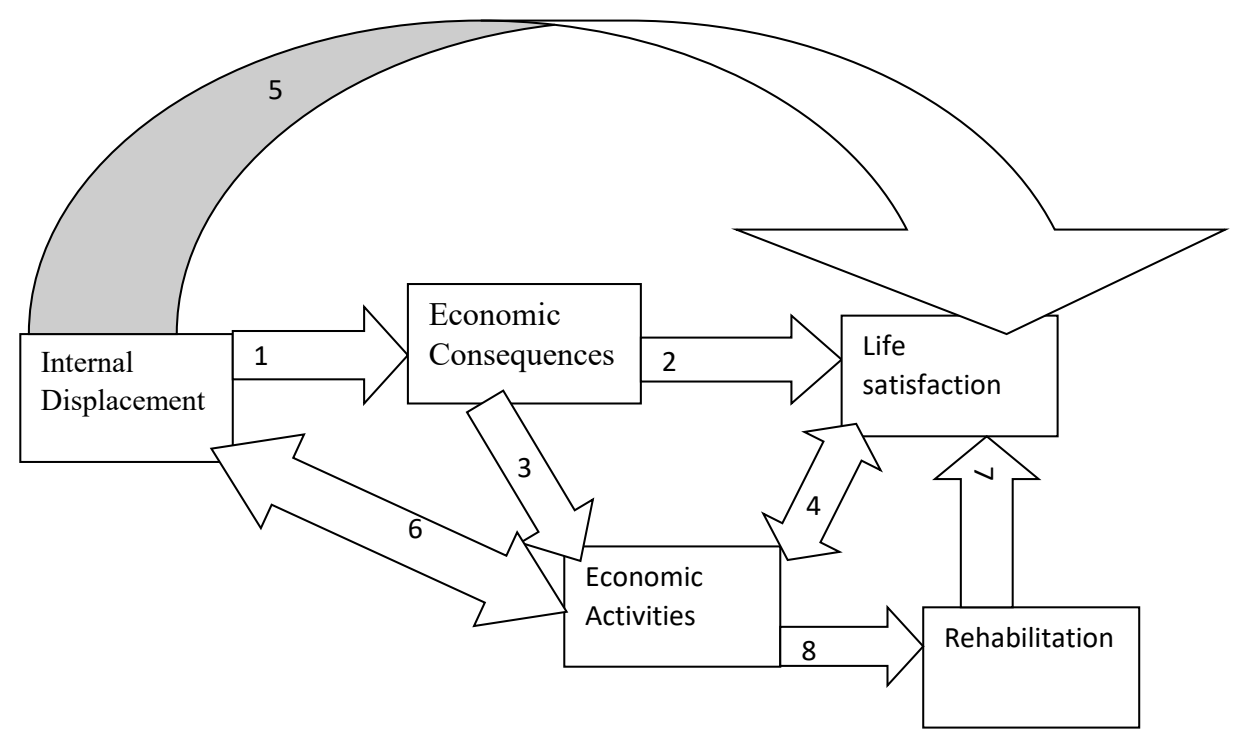

\section{Figure 1: Conceptual Framework}


Arrows 2 and 3 show that displacement consequences affect SWL and economic activities. SWL may change if the IDP is relocated to an unfavourable area or because of changes in reference groups as proposed by the social comparison theory which states that SWL is determined by comparing with neighbours' SWL. However, it is also plausible to find individuals getting satisfied with life as may be explained by availability of public goods (Ali, Murshed \& Papyrakis, 2019). Alternatively, the stoicism theory notes a gently flowing life meaning SWL may not change despite displacement.

The economic consequences force IDPs to employ coping strategies. Bozzoli et al. (2011) acknowledge that little attention has been paid to economic activities of IDPs. Thus, after displacement, IDPs engage in coping strategies to survive, the choice of which depends on gender and social capital, among others. These coping strategies may also affect SWL among IDPs (Arrow 4) with a probability of feedback causality.

Internal displacement may directly affect economic activities of households (Arrow 5) without any losses. Because of the rarity in which displacement can happen without loss of assets, this scenario is likely to be rare. Economic activities may also lead to internal displacement (Arrow 6)as in Zimbabwe and other countries like Ghana, where prior to displacement households may have been considered to be engaging in activities that are not of national interest. Examples include, colonial governments grabbed land under the auspices of being underutilised. Thus, development projects, if weighed and found to be less beneficial to the nation than what inhabitants are doing households would not be moved. The same could be said in Ghana when people were relocated in Tarkwa district to pave way for mining and for Akosombo, Kpong and Bui dams.

Another interlinkage propounded here is that economic activities of the displaced lead to rehabilitation (Arrow 8). The rehabilitation may lead to satisfied IDPs (Arrow 7) hence a productive population of IDPs. There is a possibility that when well rehabilitated, households may be more productive than the non-displaced one thereby actively contributing more to the national cake despite previous experience of displacement.

The study acknowledges the possibility of SWL affecting economic activities of IDPs (Arrow 4). Other areas that the study considers of interest are the possibilities of displacement affecting SWL (Arrow 5) without economic consequences being intermediating variables. Also, economic activities done by IDPs may lead to the 
IDPs' rehabilitation leading to SWL. From the conceptual framework, a number of conclusions have been made in the conclusions section.

\section{METHODOLOGY}

The study's aim was to find out the knowledge gap in literature as far as resettlement studies are concerned. Based on the calls by Cernea (1995), Caspary (2007) and Ruiz and Vargas-Silva (2013) that economists have ignored resettlement studies, the study intended to identify the extent to which economists have responded to these calls and to what extent MID has been researched on. To achieve these objectives, the following was done.

The selection of papers for review was based on various aspects but mainly guided by the objectives above. The first consideration was on whether a paper was on economic consequences of life changing events. The understanding was that these events' consequences affect economic activities and SWL. Studies were also classified according to whether they have an economics bias or any other discipline other than economics as well as whether they particularly focussed on MID. The economics bias was meant to reveal whether the gaps claimed have been addressed while the mining aspect represented the extent to which MID has been researched on. The reference period covered is mainly the 1980 s to 2020 .

The review was limited to published journal articles, conference presentations and grey literature as well as working papers. Both theoretical and empirical papers were candidates for review. These were used to guide the underpinnings of the study. Firstly, abstracts were critically analysed to determine the flair the article has. If the article was found to meet the eligibility criteria, it was critically analysed. Therefore, an integrative approach was used in the review process. In selecting papers, key terms used to identify articles include, internal displacement, consequences or risks, SWL, livelihoods and coping strategies.

\section{RESULTS AND DISCUSSION}

After displacement, IDPs lose land resulting in economic decapitalisation (Cernea, 1997a). Because most rural households depend on land for survival, being displaced is tantamount to impoverishment, for example, by being unable to grow food. Other ripple effects from landlessness such as food insecurity loom (Cernea, 1991,1995, 1996, 1997a, 2003; Hoshour \& Kalafut, 2007; Petkova et al., 2009; Carrillo, 2009; Agbley, 2019). For instance, after being displaced by Ghana's Bui dam, 
households became food insecure (Yankson et al., 2017; Koranteng \& Shi, 2018). Economic marginalisation sprouts when individuals are displaced with individuals being denied access to things like credit because of probability of non-payment. For instance, after displacement social disintegration results and households are resettled among unfamiliar people thereby increasing IDPs' chances of being denied credit. Intertemporal theory predicts that loss of credit affects future income again inhibiting economic activities requiring external funding.

Among DID studies, dams are on top with Cernea (1997a), Hughes (2006) and Mashingaidze (2012) establishing that Lake Kariba led to loss of land. Gross (2008) showed that Merowe dam led to UN intervention because of the size of the displacement and its consequences. It has also been shown that dams in Ghana have caused significant displacements (Gyau-Boakye, 2001; Yankson et al., 2017; Koranteng \& Shi, 2018). Mburugu (1994) also found landlessness in Kenya's Kiambere Hydropower. The extent of dam-induced displacements has led to the establishment of the WCD. With such information, it may be plausible to conclude that a lot has been done on dams.

Under DID, Agbley (2019) established that displacement for biofuel operations in Ghana led to landlessness. Mutopo (2011) in Zimbabwe, concurs by establishing that biofuel companies led to landlessness in Nuanetsi ranch. Therefore, some aspects of DID have been covered in literature with less focus being made on mining.

Furthermore, conflict-induced displacements have been articulated. Imai and Weinstein (2000) considered the economic consequences of war and found negative consequences of war on economic growth. Ibanez and Moya (2009) showed that conflicts lead to asset losses and asset accumulation afterwards is only attained by a few. Calderona and Ibanez (2009) showed that forced migration led to reduced incomes in Colombia because of reduced economic activities. Reduced incomes have caused reduced consumption among Ugandan IDPs (Fiala, 2012). Since income is a significant determinant of well-being, it can therefore be true that SWL changes after displacement. Several authors confirmed the negative consequences of conflict (Oucho, 2005; Acharya, 2009; Hovil, 2012). The cited studies may also indicate that conflict-induced displacement has been well articulated in literature.

The preceding three paragraphs show that MID is lagging behind in research. Focus has been mainly on dams and conflicts. Therefore, little is currently known about MID yet this category of displacement has peculiar characteristics that warrant attention (Owen \& Kemp, 2015). As a consequence of displacement, social 
disarticulation reduces households' reliance on social capital (Schweitzer et al., 2007; Mukwada, 2012). For example, households in Africa lend to each other even small items like salt. This lending, however, is dependent on social connectedness. So when socially connected households are relocated to different areas, they lose social capital thereby worsening their livelihoods after displacement. Social capital has been found to be a key determinant of SWL (Froh, 2007; Colic-Peisker, 2009; Dhurup \& Surujlal, 2009; Frey \& Stutzer, 2002; Stutzer \& Frey 2012). The reduction in SWL resulting from loss of social capital may be explained by marginalisation and loss of reciprocity. Because of social capital, individuals feel obliged to reciprocate the assistance; therefore, the loss of this reciprocity is felt among IDPs thereby reducing SWL. Moreso, marginalisation is minimised if one is within members of their own community.

Consequences of forced migration have been researched on but MID's consequences still lag behind. The above paragraphs have shown that conflict-induced displacements and some DIDs have so far some known consequences. Therefore, room still exists as to what consequences MID has since Owen and Kemp (2015) noted that mining is unique.

Displacement is not always an end to life. This implies that life still goes on despite having been displaced, therefore, survival tactics need to be devised. Most economic agents are forward looking hence given a chance they devise ex-ante risk management strategies (Acevedo, 2016; Mukarami, 2017). However, in most displacement cases, ex-post strategies are applied. Such strategies include asset disposal, use of social capital and livelihood diversification (Davies, 1993; Dercon, 2000).

Asset disposal as a coping strategy has been found to be unsustainable (Bird et al., 2002; Deressa et al., 2010). That asset disposal has long term negative consequences is explained by the fact that IDPs will have already lost some assets, thus, continuous reduction in asset ownership impoverishes IDPs. The resultant poverty is likely to reduce SWL viewed from material well-being. Materialism has been used as a determinant of SWL with the conceptualisation that "... possession brings happiness..." (Gornik-Durose, 2019). The ability to acquire material things will have been reduced by loss of income associated with displacement (Cernea, 1997a).

Previous studies on economic activities concentrated more on the coping strategies of conflict-induced IDPs, for instance, in Mozambique (Bruck, 2004; Bruck \& Danzer, 2007) and Uganda, (Bozzzoli, Bruck \& Muhummuza, 2011). Extant literature 
also concentrated on coping strategies of refugees for instance Khawaja et al. (2008). Therefore, literature is still scant on economic activities among MID IDPs.

Since displacement is a life changing event, SWL is likely to be affected by displacement. For instance, Agbley (2019) noted that land grabs have snowballing effects on food security and well-being implying a link between land disposition and well-being. Like most other stressful life events, displacement is likely to affect SWL negatively. Diener, Sapyta and Suh (1998) claim that happiness or SWL is very important as a goal in life and therefore Anielski (2007, p. xvii) noted that happiness is “...our genuine wealth". Despite this importance and SWL being a genuine wealth, Ferrer-i-Carbonell (2013) acknowledged that economists have generally ignored this important study area.

The reduced SWL after displacement (Mandishekwa \& Mutenheri, 2019) coupled with economic consequences of displacement results in an economically unproductive population since a happy population tends to be productive. The level of SWL is likely to affect IDPs' choice of livelihood activities. Therefore, there is likely to be a link among displacement consequences, economic activities and SWL among the displaced. What remains to be known is the transmission mechanism through which economic consequences of displacement are transmitted to the other two aspects of displacement.

The consequences of displacement are sometimes gender biased with females being hard hit by displacement more than males (Benjamin \& Fancy, 1998; Mutopo, 2011; Oucho, 2005; Acharya, 2009; Hovil, 2012; Majidi \& Hennion, 2014) sometimes because of the roles enshrined in traditions. Onyango $(2012,26)$ said "Men are not born men but are culturally made men" implying that culture shapes norms expected of men and women. For instance, wives were exposed more to displacement risks in Nuanetsi because they are expected to remain at home while husbands go to work (Mutopo, 2011). However, it also has been noted that displacement changes gender roles (Mertus, 2003) with women sometimes becoming empowered.

Gender differentials in consequences have implications on rehabilitation. Cernea (1995a) propounded the resettlers' income recovery curve. In line with this curve, if women are affected more, their recovery will take longer to catch up with that of men and non-displaced households. This will affect women's economic empowerment. 
From a feminist sociological perspective, Abbott, Wallace and Tyler $(2005,9)$ acknowledged that "...issues of concern to women are frequently overlooked or seen as unimportant". This implies that from the feminist perspectives, societies, usually patriarchal ones, generally ensure male domination (Madsen, 2000). By so doing, economic empowerment of displaced women is hampered.

With differential effects in mind, changes in economic activities and SWL after displacement are likely to be gendered as well. Males and females employ different coping strategies (Spence, Lachlan \& Burke, 2007; Renner \& Salem, 2009) probably because women have been found to be more risk-averse (Borghans, Gosteyn, Heckman \& Meijers, 2009; Nelson, 2012). The likelihood of women engaging in new economic activities after displacement may therefore be low.

One of the objectives of this review was to show the linkages among the three parts related to displacement. From Figure 1, a Displacement Triad was constructed which illustrates the interrelatedness of the main thesis of this study. This triad is shown in Figure 2 and links the main components of this study.

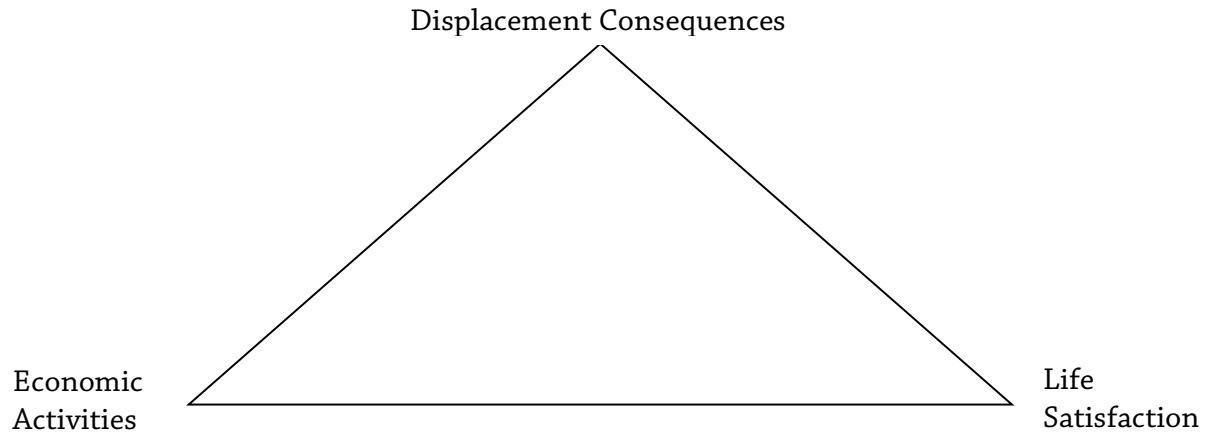

\section{Figure 2: The Displacement Triad}

The Displacement Triad summarises the proposition that displacement has ripple effects summarised as displacement consequences, changes in SWL and economic activities. These may be bi-directional as proposed in Figure 1. From an economist's perspective, it is not enough to know only the consequences of displacement but it is equally important to get an understanding of the implications of displacement on economic activities and SWL. These will help to build a culture of inclusivity when proposing resettlements since forced resettlement has the potential to affect quality of life. By putting these aspects on the discussion table, policy-makers and mining-companies will be able to have a strong and proper understanding of their actions. 
It is also plausible to propose SWL and economic activities as economic consequences of displacement. Therefore, in addition to consequences suggested by Cernea (1995a, 1997a), this study suggests that there is need to add SWL and economic activities. However, Cernea's model cannot be totally ruled out because one has to remember that his views were from anthropology while this study is more transdisciplinary.

While Cernea proposed that displacement has risks as summarised in the IRR model, the current study proposes that these consequences were not adequately addressed. It, therefore, proposes more literature extension by bringing in the changes in SWL and economic activities after displacement. The underpinning assumption is that most of the consequences are negative, therefore, likely to negatively affect economic activities and SWL among IDPs.

\section{CONCLUSIONS}

The study revealed that DID has been widely researched on, but little has been done specifically on MID yet mining is significant in displacement. This is against the fact that mining is also significant in the economic development of some nations, like Botswana, Ghana, Zambia and Zimbabwe, and has consequences that may be unique from other DIDs. For instance, MID may involve a stepwise land take approach necessitating displacements at any stage of the mining activities.

Results reveal that little attention has been made to resettlement research by economists. Mostly anthropologists, sociologists and psychologists have done a lot in this area of research. Therefore, more still needs to be known from economists' perspective. Development economists are recommended to come on board in research on DIDR. MID has generally been understudied with conflict-induced and dam-induced displacements having attracted much attention. However, given the extent of mining activities in Africa, there is need to refocus attention on mining's consequences. Given the IDP population, researchers and policy-makers are encouraged to shift attention from refugees and focus more on IDPs. This will assist a lot since IDPs currently outweigh refugees especially in Africa (Maru, 2011; Ferris, 2012).

This study shows that MID IDPs lose their possessions. With these losses come changes in livelihood thereby requiring IDPs to employ coping strategies. Since displacement leads to economic losses and changes in economic activities, SWL changes accordingly. For example, food insecurity as a result of displacement, leads households to engage in new economic activities. These new activities may not 
result in food security. Being anxious about food adequacy is likely to affect SWL. Thus, MID must be considered in such contexts before forcibly relocating people. Displacement also affects IDPs' economic activities with coping strategies being employed. Well known common coping strategies include asset disposal, livelihoods diversification and consumption and income smoothing. It has been found that displacement has negative consequences on SWL. Therefore, a displacement triad has been proposed to show the links among displacement consequences, economic activities and SWL.

The study revealed that DID is premised on neoliberal economics arguments which expect benefits to accrue to everyone despite the negative consequences to IDPs. The claim that benefits will cascade to the whole country is not always the case. For instance, Pareto optimality condition predicts that it is impossible to improve one person's welfare without negatively affecting another person's welfare. Therefore, by displacing people, the government acts as a dictator as predicted by Arrow's impossibility theorem, where the government is given room to dictate when faced with no other feasible option. On the other hand, the Kaldor-Hicks efficiency criterion notes that improvement in welfare is only possible if the losers place more weight on gains than losses which according to rationality is likely to be rare among IDPs given the losses incurred.

Economic activities, SWL after displacement and consequences of displacement have not been linked in previous research. The transmission mechanism between displacement and SWL still needs to be done. The integrative review in this study revealed a possible link as in Figures 1 and 2. Therefore, a quantitative analysis of the extent to which this link exists needs attention. This may be attained by use of structural equation modelling. 


\section{REFERENCES}

Aboagye, S. (2014). Mining and resettlement of communities in Ghana: Exposing the harm caused by forced displacement and relocation. www.miningwatch.ca

Abbott, P., Wallace, C. \& Tyler, M. (2005). An Introduction to Sociology: Feminist Perspectives, $3^{\text {rd }}$ Edition. Routledge.

Acevedo, M. C. (2016). What do we know about the effectiveness of ex-ante risk management strategies in Latin America and the Caribbean?, Background paper for the World Bank book "Aggregate Shocks, Household Welfare and Ex-ante Risk Management Strategies in Latin America and the Caribbean."

Acharya, A. K. (2009). The dynamics of internal displacement, forced migration and vulnerable to trafficking in Mexico. J. Hum Ecol, 27(3), 161-170.

Adeola, R. (2017). The responsibility of businesses to prevent development-induced displacement in Africa, 17 African Human Rights Law Journal, 244-264.

Adeniyi, A. B, Daud, A. S., Amao, O. \& Omotayo, A. O. (2016). Determinants of Rural Women's Livelihood in Ibarapa North Local Government Area of Oyo State, Nigeria, Journal of Human Ecology, 56,1-2, 84-90.

Agbley, G. K. (2019). Land grabbing and the gendered livelihood experience of smallholderfarmers in Northern Ghana: Through a human development and capability lens. Ghana Journal of Development Studies, 16(1), 155-180.

Ali, S., Murshed, S., M. \& Papyrakis, E. (2019). Happiness and the Resource Curse, Journal of Happiness Studies. https://doi.org/10.1007/s10902-019-00080-3.

Amisi, B. B. (20060). An Exploration of the livelihood strategies of Durban Congolese Refugees. Centre for Civil Society Research Report, 46(1), 195-229.

Amit, K. (2009). Determinants of life satisfaction among immigrants from Western countries and from the FSU in Israel, Social Indicators Research, 96, 515-534.

Anielski, M. (2007). The Economics of Happiness: Building Genuine wealth, New Society Publishers.

Benjamin, J. A. \& Fancy, K. (1998). The gender dimensions of internal displacement: Concept paper and annotated Bibliography, UNICEF/IDP Gender Issues Paper.

Bird, K, Shepherd, A., Scott, A. \& Butaumocho, B. (2002): Coping Strategies of Poor Households in Semi-Arid Zimbabwe, Final Technical Report for Natural Resources Systems Programme (NRSP), Project Number: R7545.

Borghans, L., Golsteyn, B. H. H, Heckmen, J. J \& Meijers, H (2009). Gender Differences in Risk Aversion and Ambiguity Aversion, NBER Working Paper No. 14713. 
Bozzoli, C., Bruck, T., \& Muhumuza, T. (2011). Activity choices of Internally Displaced Persons and Returnees: Quantitative Survey Evidence from Post-War Northern Uganda, Microcon Research Working Paper 53.

Bruck, T. (2004). Coping strategies in post-war rural Mozambique, HiCN Working Paper 02.

Bruck, T. \& Danzer, A. M. (2007). Coping with peace: Household activity choices in post-war Northern Mozambique, German Institute for Economic Research.

Cagoco-Guiam, R. (2013). Gender and livelihoods among internally displaced persons in Mindanao, Philippines. The Brookings-London School of Economics Project on Internal Displacement.

Calderon, V. \& Ibanez, A. M. (2009). Labor market effects of migration-related supply shocks: Evidence from internally displaced population in Colombia. MICROCON research working paper 14.

Carrillo, A., C. (2009). Internal displacement in Colombia: humanitarian, economic and social consequences in urban settings and current challenges. International Review of the Red Cross, 91(875), 527-546.

Caspary, G. (2007). The impact of development-induced displacement on human security, a study of dam finance, Human Security Journal, 4, 70-81.

Cernea, M. M. (1991). Knowledge from social science for development policies and projects. In Cernea, M. M. (Ed.). Putting people first: Sociological variables in rural development, (2 ${ }^{\text {nd }}$ ed., pp. 1-41). Oxford University Press.

Cernea, M. M. (1994). Using knowledge from social science in development projects, Project Appraisal, 9(2), 83-94.

Cernea, M. M. (1995). Understanding and preventing impoverishment from displacement: Reflections on the state of knowledge, Journal of Refugee Studies, $8(5), 245-264$.

Cernea, M. M. (1996). Public Policy Responses to Development-Induced Population Displacements, Economic and Political Weekly, 31(24), 515-1523.

Cernea, M. M. (1997a). The risks and reconstruction model for resettling displaced populations, World Development, 25(1), 1569-1587.

Cernea, M. M. (1997b). African Involuntary Population Resettlement in a Global Context, Social Assessment Series 045. World Bank.

Cernea, M. M. (Ed) (1999). The Economics of involuntary resettlement: Questions and challenges. World Bank. 
Cernea, M. M. (2000). Risks, safeguards and reconstruction: A model for population displacement and resettlement, Economic and Political Weekly, 35(41), 36593678 .

Cernea, M. M. (2003). For a New Economics of Resettlement: A sociological critique of the compensation principle. International Social Science Journal, 175, 22-48.

Cernea, M. M. \& Schmidt-Soltau, K. (2003). The end of forcible displacements? Conservation must not impoverish people, Policy Matters, 12, 42-51.

Cohen, R. (2000). The forgotten ones: A survey of recent literature on displaced persons. Harvard International Review, 86-87.

Colic-Peisker, V. (2009). Visibility, settlement success and life satisfaction in three refugee communities in Australia, Ethnicities, 9(2), 175-199.

Cook, C. \& Mukendi, C. (1994). Involuntary Resettlement in Bank-Financed Projects: Lessons from Experience in Sub-Saharan Africa. In C. C. Cook, (Ed.), Involuntary Resettlement in Africa, (pp.33-48) World Bank Technical Paper No. 227.

Davies, S. (1993). Are coping strategies a cop out? Ids Bulletin, 24(4), 60-72.

Dercon, S. (2000). Income risk, coping strategies and safety nets, Centre for Study of African Economies, Oxford University, WPS/2000.26.

Deressa, T. T., Ringler, C. \& Hassan, R. M. (2010). Factors Affecting the Choices of Coping Strategies for Climate Extremes: The Case of Farmers in the Nile Basin of Ethiopia, IFPRI Discussion Paper 01032.

Dhurup, M. \& Surujlal, J. (2009). Social support for health-related leisure activity of the elderly and the relationship with health status and life satisfaction. African Journal for Physical, Health Education, Recreation and Dance (AJPHERD, September 2009 (Supplement), 16-32.

Diener, E., Sapyta, J. J., \& Suh, E. M. (1998). Subjective well-being is essential to wellbeing. Psychological inquiry, 9, 33-37.

Downing, T. E. (2014). Does the Kosovo power project's proposed forced displacement of Kosovars comply with international involuntary resettlement standards? The Kosovo civil society consortium for sustainable development, http:// allthingsaz.com/wp-content/uploads/2014/o4/Final-Draft-DowningInvoluntary-Resettlement-at-KPP-Report-2-14-14.pdf (accessed 12/07/14).

Dwivedi, R. (2002). Models and methods in development-induced displacement (Review Article), Development and Change, 33(4), 709-732. 
Eriksen, J. H. (1999). Comparing the economic planning for voluntary and involuntary resettlement. In M. M. Cernea (Ed.). The economics of involuntary resettlement: Questions and challenges (pp. 83-146), World Bank.

Ferrer-i-Carbonell, A. (2013). Happiness Economics, Series, Journal of the Spanish Economic Association, 4, 35-6o.

Ferris, E. (2012). Internal displacement in Africa: An overview of trends and opportunities, Presentation at the Ethiopian community development council annual conference "African refugee and immigrant lives: Conflict, consequences, and contributions" 2-4 May 2012.

Fiala, N. (2012). The Economic Consequences of Forced Displacement, HiCN working Paper 137

Frey, B. S. \& Stutzer, A. (2002). The economics of happiness. World Economics, 3(1), $1-17$.

Froh, J. J. (2007). Interpersonal relationships and irrationality as predictors of life satisfaction. The Journal of Positive Psychology, 2(1), 29-39.

Getanda, E. M., Papadopoulos, C. \& Evans, H. (2015): The mental health, quality of life and life satisfaction of internally displaced persons living in Nakuru County, Kenya, BMC Public Health, 15(755), 1-9.

Gornik-Durose, M. E. (2019). Materialism and Well-Being Revisited: The Impact of Personality, Journal of Happiness Studies, https://doi.org/10.1007/s10902-019ooo89-8.

Gross, T. L. (2008). Improvement with impunity: Development-Induced displacement and the Guiding Principle 6(2) (c). Proportionality test applied to the Merowe Dam project in Sudan. American University International Law Review, 24(2), 377406.

Gyau-Boakye, P. (2001). Environmental impacts of the Akosombo Dam and effects of climate change on the lake levels. Environment, Development and Sustainability, 3, 17-29. https://doi.org/10.1023/a\%3a1011402116047

Hardin, G. (1968). The Tragedy of the Commons, Science, New Series, 162(3859), 12431248.

Harrel-Bond, B. E. \& Voutira E. (1992). Anthropology and the study of refugees. Anthropology Today, 8(4), 6-10.

Hoadley, M. (2008). Development-induced displacement and resettlementimpoverishment or sustainable development, School of Mining Engineering, University of Witwatersrand, South Africa. 
Hodgson, G. M. (2012). On the Limits of Rational Choice Theory, Economic Thought, 1, 94-108.

Hoshour, K. \& Kalafut, J. (2007). A growing global crisis, development-induced displacement and resettlement, International Accountability Project Issue Paper.

Hovil, L. (2012). Gender, transitional justice, and displacement: Challenges in Africa's Great Lakes Region, International center for transitional justice,www. brookings.edu/idp

Hughes, D. M. (2006). Whites and water: How Euro-Africans made nature at Kariba Dam. Journal of Southern African Studies, 32(4), 823-838.

Ibanez, A. M. \& Moya, A. (2009). Do conflicts create poverty traps? Asset losses and recovery for displaced households in Colombia, MICROCON Research working Paper 10.

IDMC (2008). The Many faces of displacement: IDPs in Zimbabwe, www.internaldisplacement.org

IDMC (2011). Internal displacement in Africa, Global overview 2011, www.internaldisplacement.org

IDMC (2015a). Global Overview 2015: People internally displaced by conflict and violence, www.internal-displacement.org

IDMC (2015b). Quarterly update, July-September 2015, www.internal-displacement. org

IDMC (2016). Global Report on Internal Displacement, www.internal-displacement. org

IDMC (2018). Global Report on Internal Displacement, www.internal-displacement. org

Imai, K. \& Weinstein, J. (2000). Measuring the economic impact of civil war, CID working paper no. 51 .

Jacobsen, K. \& Landau, L. B. (2003). The dual imperative in refugee research: Some methodological and ethical considerations in social science research on forced migration. Disasters, 27, 185-206.

Lwabukuna, O. K. (2011). Internal Displacement in Africa: African solutions to African problems? Challenges and prospects, Journal of Internal Displacement 1(1), 131-141. 
Kemp, D., Worden, S. \& Owen, J. R. (2016). Differentiated social risk: Rebound dynamics and sustainability performance in mining. Resources Policy, 50, 1926.

Khawaja, N. G., White, K. M., Schweitzer, R. \& Greenslade, J. (2008). Difficulties and copies strategies of Sudanese refugees: A qualitative approach. Transcultural Psychiatry, 45(3), 489-512.

KNOMAD (2018). Migration and remittances: Recent developments and outlook,migration and development brief 29, World Bank, Washington D.C.

Koranteng, R. T. W. \& Shi, G. (2018). Assessing the Resettlement Scheme of the Bui Hydro - Project Using the Social Len., Journal of Sustainable Development, 11(4), 288-315.

Lama, M. P. (n.d). Internal displacement in India: causes, protection and dilemmas. Forced Migration Review, 8, 24-26.

Lichbach, M. I. (2003). Is Rational Choice Theory All of Social Science?, University of Michigan Press.

Madsen, D. L. (2000). Feminist Theory and Literary Practice. Pluto Press.

Magadza, C. H. D. (1994). Social impacts of the creation of Lake Kariba. In Cook. C. C (Ed): Involuntary resettlement in Africa: Selected papers from a Conference on environment and settlement issues in Africa, World Bank technical paper Number 227.

Magaramombe, G. (2010). Displacement in place: Agrarian displacements, replacements, and resettlement among farm workers in Mazowe District. Journal of Southern AfricanStudies, 36(2), 361-375.

Majidi, N. \& Hennion, C. (2014). Resilience in displacement? Building the potential of Afghan displaced women, Journal of Internal Displacement, 4(1), 77-91.

Malle, B. F. (2011). Attribution theories: How people make sense of behavior. In D. Chadee (Ed.), Theories in social psychology (pp. 72-95). Wiley-Blackwell.

Mandishekwa, R. \& Mutenheri, E. (2018). The economic consequences of internal displacement in Arda Transau, Zimbabwe. Paper presented at the $8^{\text {th }}$ KESSAAISA-Multimedia University, International interdisciplinary conference on development from below and from above in Africa held at Multimedia University of Kenya, 27-30 ${ }^{\text {th }}$ June 2018.

Mandishekwa, R. \& Mutenheri, E. (2019). Quantification and modelling life satisfaction among internal displacees in Arda Transau, Zimbabwe. Int. J. Happiness and Development, 5(4), 298-327. 
Maru, M. T. (2011). The Kampala Convention and its contribution in filling the protection gap in international law, Journal of Internal Displacement, 1(1), 91130.

Mashingaidze, T. M. (2012). Living and struggling on the margin. A post-relocation history of the Zimbabwean Tonga's livelihood in Binga District, Unpublished PhD dissertation, University of Minnesota.

Mathis, K. \& Steffen, A. D. (2015). From Rational Choice to Behavioural Economics: Theoretical Foundations, Empirical Findings and Legal Implications. In K, Mathis (Ed.), European Perspectives on Behavioural Law and Economics (pp. 3148). Springer International Publishing.

Mburugu, E. K. (1994). Dislocation of settled communities in the development process: The case of Kiambere hydroelectric project. In C., C. Cook (Ed.). Involuntary resettlement in Africa. World Bank technical paper No. 227, World Bank.

McDonald-Wilmsen, B. \& Webber, M. (2010). Dams and displacement. Raising the standards and broadening the research agenda. Water Alternatives 3(2), 142161.

Mertus, J. (2003). Sovereignty, gender, and displacement. In E. Newman \& J. van Selm, (Eds.), Refugees and forced displacement: International security, human vulnerability, and the State (pp. 250-273). United Nations Univerisity Press.

Mooney, E. D. (2003). Towards a protection regime for internally displaced persons. In E. Newman and J. van Selm (Eds.), Refugees and Forced Displacement: International Security, Human Vulnerability, and the State (pp. 159-180). United Nations University Press.

Mukarami, E. (2017). Household consumption risk and coping strategies in Tajikistan: Evidence from household surveys, ADBI Working Paper 738, May 2017.

Mukwada G. (2012). Scales of vulnerability: resettlement and exposure to multiple stressors and shocks in Zimbabwe. J Hum Ecol, 40(2), 101-113.

Mutopo, P. (2011). Gendered dimensions of land and rural livelihoods: The case of new settler farmer displacement at Nuanetsi Ranch, Mwenezi District, Zimbabwe, Paper presented at the International Conference on Global Land Grabbing, 6-8 April 2011, University of Sussex

Nelson, J. A. (2012): Are women really more risk-averse than men?, Institute for New Economic Thinking, INET Research Note \#012.

Nelson, J. A. (2012): Are Women Really More Risk-Averse than Men?, Institute for New Economic Thinking, INET Research Note \#012. 
Ng, S. T., Tey, N. P. \& Asadullah, M. N. (2017). What Matters for Life Satisfaction among the oldest-old? Evidence from China. PLoS ONE, 12(2), o17 - 1799.

Nyawo, V. Z., Goredema, D. \& King, M. D. (2012). The socio-economic impact of Chiadzwa informal diamond mining on the lives of the people of Chiadzwa and its hinterland. The Dyke, 6(2), 6-21.

Ootegem, L. V. and Verhofstad, E. (2016) 'Well-being, life satisfaction and capabilities of flood disaster victims', Environmental Impact Assessment Review, 57, 134-138.

Onyango, E. O. (2012). Manhood on the margins: Failing to be a man in post-conflict Northern Uganda. MICROCON research working paper 68.

Opukri, C. O. \& Ibaba, I. S. (2008). Oil Induced Environmental Degradation and Internal Population Displacement in the Nigeria's Niger Delta, Journal of Sustainable Development in Africa, 10(1), 173-193.

Oucho, J. O. (2005). Internal displacement of population in the SADC Region: An overview, Paper presented at the seminar on internal displacement in the Southern African Development Community (SADC), Region, Gaborone, Botswana, 24-25 August 2005.

Owen, J. R. \& Kemp, D. (2015). Mining-induced displacement and resettlement: A critical appraisal, Journal of Cleaner Production, 87, 478-488.

Petkova, V., Lockie, S., Rolfe, J. \& Ivanova, G. (2009). Mining developments and social impacts on communities: Bowen basin case studies. Rural Society, 19(3), 211228.

Planning Alliance (2005): NewMont Ghana Gold Limited: Resettlement Action Plan [Rev.1] Ahafo South Project, Accra, Ghana.

Renner, W. \& Salem, I. (2009). Post-traumatic Stress in Asylum Seekers and Refugees from Chechnya, Afghanistan, and West Africa: Gender Differences in Symptomatology and coping. International Journal of Social Psychiatry, 55(2), 99-108.

Renner, W. \& Salem, I. (2009). Post-traumatic stress in asylum seekers and refugees from Chechnya, Afghanistan, and West Africa: Gender differences in symptomatology and coping, International Journal of Social Psychiatry, 55(2), 99-108.

Ritzer, G. (2011). Sociological Theory (8 ${ }^{\text {th }}$ Edition). McGraw-Hill.

Rubinstein, A. (2006). Lecture Notes in Microeconomic Theory. Princeton University Press, New Jersey. 
Ruiz, I. \& Vargas-Silva, C. (2013). The economics of forced migration. The Journal of Development Studies, 49(6), 772-784.

Schweitzer R., Greensdale J. H. \& Kagee A. (2007). Coping and resilience in refugees from Sudan: a narrative account. Aust N. Z. J. Psychiatry 41(3), 282-288.

Scudder, T. (1985): A Sociological Framework for the Analysis of New Land Settlements. In M. M. Cernea (ed.), Putting People First. Sociological Variables in Rural Development, (2, pp. 148-187), Oxford University Press.

Sen, A. K. (1999). Development as freedom, Alfred. A Knopf Inc.

Spence, P. R., Lachlan, K. A. \& Burke, J. M. (2007). Adjusting to uncertainty: Coping strategies among the displaced after Hurricane Katrina, Sociological Spectrum, $27(6), 653-678$.

Stanley, J. (2004). Development-induced displacement and resettlement, Forced migration organisation, 22.

Stutzer, A. \& Frey, B. S. (2012). Recent Developments in the Economics of Happiness: A Selective Overview, IZA Discussion Paper No. 7078.

Terminski, B. (2012). Mining-Induced Displacement and Resettlement: Social Problem and Human Rights Issue (A Global Perspective). http://indr.org/wpcontent/uploads/2013/o4/B.-Terminski-Mining-Induced-Displacement-andResettlement.pdf (Accessed 02/03/2020)

UNICEF Zimbabwe (2019). Zimbabwe humanitarian situation report: Cyclone SitRep\#2 (15-24 March, 2019), UNICEF.

United Nations. (2004). United Nations Guiding Principles on Internal Displacement U.N. Office of the Commissioner for Human Rights, United Nations.

U.S Committee for Refugees (2002): “World Refugee Survey 2002”, http://www. refugees.org/news/press_releases/2002/wrsO2_PRstat2.cfm.

Vanclay, F. (2017). Project-induced displacement and resettlement: From impoverishment risks to an opportunity for development? Impact Assessment and Project Appraisal, 35(1), 3-21.

Vandergeest, P. (2003). Land to some tillers: Development-induced displacement in Laos, UNESCO, ISSJ 175, 47-56.

Vlaev, I. (2018). Local Choices: Rationality and the Contextuality of Decision-Making, Brain Sciences, 8(8), 2-22.

Weiner, B. (1985). An attributional theory of achievement motivation and emotion, Psychological Review, 92(4), 548-573. 
Weiner, B. (2008). Reflections on the history of attribution theory and research: People, personalities, publications, problems, Social Psychology, 39(3), 151-156.

Yankson, P. W. K., Asiedu, A. B. Owusu, K. Urban, F. \& Siciliano, G. (2017). Thelivelihood challenges of resettled communities of the Bui dam project in Ghana and the role of Chinese dam-builders, Dev. Policy Rev., DOI: 10.1111/dpr.12259.

Zetter, R. (2014). Reframing displacement crises as development opportunities, policy brief prepared for the Global initiative on solutions, Copenhagen Roundtable, 2-3 April 2015. 